\title{
Short communication: A comparison between purebred Holstein and Brown Swiss $\times$ Holstein cows for milk production, somatic cell score, milking speed, and udder measurements in the first 3 lactations
}

\author{
S. Blöttner, ${ }^{*}$ B. J. Heins,, M. Wensch-Dorendorf, ${ }^{*}$ L. B. Hansen, $†$ and H. H. Swalve ${ }^{* 1}$ \\ ${ }^{*}$ Institute of Agricultural and Nutritional Sciences, University of Halle, 06099 Halle, Germany \\ †Department of Animal Science, University of Minnesota, St. Paul 55108
}

\section{ABSTRACT}

Brown Swiss $\times$ Holstein $(\mathrm{BS} \times \mathrm{HO})$ crossbred cows $(\mathrm{n}=55)$ and purebred Holstein $(\mathrm{HO})$ cows $(\mathrm{n}=50)$ were compared for milk yield, fat and protein production, somatic cell score, milking speed, and udder measurements for the first 3 lactations. Cows from a designed experiment were housed in a freestall barn at the experimental station of the federal state of SaxonyAnhalt, Germany, and calved from July 2005 to August 2008. Best prediction was used to determine actual production for 305-d lactations from test-day observations. For the first 3 lactations, $\mathrm{BS} \times \mathrm{HO}$ cows and $\mathrm{HO}$ cows were not significantly different for milk yield, fat and protein production, or SCS. Average milking time was significantly longer for $\mathrm{BS} \times \mathrm{HO}$ cows than for $\mathrm{HO}$ cows for first, second, and third lactations by 35,51 , and $30 \mathrm{~s}$, respectively. Average milking speed expressed as average yield per minute was significantly lower for BS $\times \mathrm{HO}$ cows than for $\mathrm{HO}$ cows for the first 3 lactations by $0.19,0.35$, and $0.19 \mathrm{~kg} / \mathrm{min}$, respectively. Front and rear teats were significantly longer for $\mathrm{BS} \times \mathrm{HO}$ cows than for HO cows. Furthermore, front and rear udder clearance was significantly lower for $\mathrm{BS} \times \mathrm{HO}$ cows compared with $\mathrm{HO}$ cows in first and second lactations. Key words: crossbreeding, Brown Swiss, production, milking speed

\section{Short Communication}

Although numerous authors (e.g., VanRaden and Sanders, 2003) have shown that purebred Holsteins are superior over any other purebred dairy breed with respect to milk yield, this superiority can be questioned when functional traits are considered. Increased selection for milk production of Holstein (HO) cows has resulted in reduced reproductive efficiency, extended calving intervals, increased health problems, increased

Received February 9, 2011

Accepted June 14, 2011

${ }^{1}$ Corresponding author: hermann.swalve@landw.uni-halle.de culling rates, and decreased productive life (GonzálezRecio et al., 2004, 2006). This deterioration in the performance for functional traits has increased interest in crossbreeding because heterosis effects, especially for functional traits, can be expected and are estimated to be of a magnitude of at least 10\% (Sørensen et al., 2008). From the above, a basic requirement for crossbreeding in dairy cattle under intensive conditions is to find a cross that performs at least as well as purebreds in milk production traits while exhibiting advantages in functional traits. One such cross could be Scandinavian Red $\times$ HO, for which Heins et al. (2006a,b,c) found distinct superiorities for calving traits, fertility, and survival while fat plus protein yield equaled that seen in HO. However, Swalve et al. (2008) found that Scandinavian Red $\times$ HO were competitive for production in first lactation only, whereas crosses of Brown Swiss $(\mathbf{B S}) \times \mathrm{HO}$ were competitive with $\mathrm{HO}$ in first and second lactations. The competitive performance of $\mathrm{BS} \times \mathrm{HO}$ compared with $\mathrm{HO}$ for milk production traits has also been shown in other studies; for example, McDowell and McDaniel (1968), Rincon et al. (1982), VanRaden and Sanders (2003), and, more recently, Dechow et al. (2007).

In analyses of dairy production, traits such as milk yield, milk quality, and milking speed should be examined jointly because recording procedures for these traits are connected and the traits are correlated with each other. For udder health and its commonly used indicator trait, SCS, results from crossbreeding studies are inconclusive. VanRaden and Sanders (2003) did not find substantial heterosis for SCS; furthermore, these authors found differences between breeds and crossbred groups that were difficult to interpret. Similarly, Heins et al. (2011) found higher SCS but lower clinical mastitis incidence when comparing Jersey $\times \mathrm{HO}$ with HO in third-lactation cows. Studies of crossbred cows that include milking speed are very limited. Walsh et al. (2007) found a slightly increased milking speed for Montbeliarde $\times \mathrm{HO}$ and Normande $\times \mathrm{HO}$ compared with Holsteins. In the study of Prendiville et al. (2010), Jersey $\times \mathrm{HO}$ crosses were on an equal level for milking 
speed and duration of milking compared with Holsteins. Analyzing data from pure Brown Swiss, Wiggans et al. (2007) emphasized the importance of considering milking speed in dairy cattle breeding.

The objectives of this study were to compare BS $\times$ $\mathrm{HO}$ cows and purebred HO cows for 305-d milk yield, fat and protein production, SCS, milking time, and milking speed for the first 3 lactations. An additional aim was to compare breed groups for udder measurements in first and second lactations.

The design of the experiment, justification for research, and background are given in Blöttner et al. (2011). Briefly, data from $50 \mathrm{HO}$ cows and $55 \mathrm{BS} \times \mathrm{HO}$ cows that calved as heifers and entered the first lactation were available. For second and third lactations of these cows, numbers were slightly reduced because of involuntary culling, and amounted to $43 \mathrm{HO}$ and $46 \mathrm{BS}$ $\times \mathrm{HO}$ cows in second lactation and $33 \mathrm{HO}$ and $35 \mathrm{BS}$ $\times \mathrm{HO}$ cows in third lactation. In each group, cows were descendants of 10 sires. For BS $\times$ HO, the numbers of progeny in first lactation per BS sire were $8(\mathrm{~A}), 5(\mathrm{~B})$, $6(\mathrm{C}), 3(\mathrm{D}), 5(\mathrm{E}), 4(\mathrm{~F}), 6(\mathrm{G}), 9(\mathrm{H}), 3(\mathrm{I})$, and $6(\mathrm{~J})$, where sires are A to J. For HO, the numbers of progeny in first lactation per HO sire were $6(\mathrm{~K}), 11(\mathrm{~L}), 2(\mathrm{M})$, $5(\mathrm{~N}), 1(\mathrm{O}), 7(\mathrm{P}), 2(\mathrm{Q}), 4(\mathrm{R}), 4(\mathrm{~S})$, and $8(\mathrm{~T})$, where sires are $\mathrm{K}$ to $\mathrm{T}$. Milk yield and fat and protein content were recorded weekly and SCS was available every $4 \mathrm{wk}$.

Seasons of calving were defined as spring (April to August) or fall (September to March) and were combined with year to form a year-season of calving effect with 6 classes: September 2005 to March 2006, April 2006 to August 2006, September 2006 to March 2007, April 2007 to August 2007, September 2007 to March 2008, and April 2008 to September 2008.

All cows in the study were milked 3 times daily. Best prediction (Cole et al., 2009) was used to predict production from test-day observations for each day of lactation, and daily production was summed for the first $305 \mathrm{~d}$ of each lactation to determine the 305-d production. Milkability traits included milking time (s), the total amount of time a cow was milked, and milking speed $(\mathrm{kg} / \mathrm{min})$, defined as milk volume divided by total milking time. For the analysis of milking time and milking speed, observations were averaged from the 3 daily milkings.

Udder measurements were front teat length, rear teat length, front teat diameter, rear teat diameter, front udder clearance, rear udder clearance, front teat width, rear teat width, teat distance front to rear, and udder size. Front and rear udder clearance was measured vertically from the floor to the udder. Front teat width was the width between front teats and rear teat width was the width between rear teats. The distance between the front and rear teats on each side were measured, but for analysis, both the right and left side measurements were combined into distance from front to rear teat. Udder size was measured from the top of rear udder to the end of the fore udder. Depending on the day of recording, udder measurements were grouped into 4 DIM classes in first parity $(0-45 \mathrm{~d}, 46-90 \mathrm{~d}, 91-138 \mathrm{~d}$, and $\geq 139 \mathrm{~d}$ ) and 3 DIM classes in second parity (46-90 d, $91-138 \mathrm{~d}$, and $\geq 139 \mathrm{~d}$ ).

For statistical analysis of milk production, SCS, milking time, milking speed, and udder measurements, the fixed effects were breed group, parity, parity nested within breed group, and year-season of calving nested within parity; cow nested within breed group was also fitted in the model as a random effect. Age at calving was not included because calving ages did not differ substantially due to the nature of the planned experiment and hence its effect was not significant. For all udder measurements, DIM classes, as defined above, were included in the model, nested within parity and breed group. The MIXED procedure (SAS Institute, 2004) was used to obtain solutions and conduct the ANOVA.

Least squares means and corresponding standard errors for 305-d milk production and SCS for BS $\times \mathrm{HO}$ and $\mathrm{HO}$ cows for their first 3 lactations are presented in Table 1. Least squares means for all these traits were not significantly $(P>0.05)$ different for $\mathrm{BS} \times \mathrm{HO}$ cows and $\mathrm{HO}$ cows for the first 3 lactations.

Consistent with the findings of the current study, Dechow et al. (2007) reported no significant differences for mature-equivalent yields for milk and fat production between $\mathrm{BS} \times \mathrm{HO}$ cows and $\mathrm{HO}$ cows. Their study was based on 2,125 purebred HO cows, 926 purebred BS cows, 256 cows from BS sire $\times$ HO dam crosses, and 18 cows from $\mathrm{HO}$ sire $\times$ BS dam crosses and additional backcrosses. However, mature-equivalent yield for protein production was significantly higher for BS $\times$ HO cows than for HO cows (Dechow et al., 2007). Similarly, Swalve et al. (2008), based on data from 481 purebred HO cows, 117 cows from Swedish Red sire $\times$ HO dam crosses, and 99 cows from BS sire $\times$ HO crosses, reported no difference in milk yield for $\mathrm{BS} \times$ $\mathrm{HO}$ cows and HO cows in first and second lactations. However, the results of Swalve et al. (2008) indicated that $\mathrm{BS} \times \mathrm{HO}$ cows were significantly superior to $\mathrm{HO}$ cows for fat and protein production in first lactation and for protein production in second lactation. In a large study based on national data from the United States, VanRaden and Sanders (2003) reported that BS $\times$ HO cows, Jersey $\times$ HO cows, and HO cows were not different for fat and protein production, although the highest milk production was found for HO cows. Similarly, Dechow et al. (2007) and Swalve et al. (2008) 
Table 1. Number of observations, least squares means (LSM), and standard errors of means for 305-d production and SCS for the first 3 lactations for Holstein (HO) versus Brown Swiss $\times$ Holstein $(\mathrm{BS} \times \mathrm{HO})$ cows $^{1}$

\begin{tabular}{|c|c|c|c|c|c|c|c|c|c|c|c|c|}
\hline \multirow[b]{3}{*}{ Production trait } & \multicolumn{4}{|c|}{ First lactation } & \multicolumn{4}{|c|}{ Second lactation } & \multicolumn{4}{|c|}{ Third lactation } \\
\hline & \multicolumn{2}{|c|}{$\mathrm{HO}(\mathrm{n}=50)$} & \multicolumn{2}{|c|}{$\mathrm{BS} \times \mathrm{HO}(\mathrm{n}=55)$} & \multicolumn{2}{|c|}{$\mathrm{HO}(\mathrm{n}=43)$} & \multicolumn{2}{|c|}{$\mathrm{BS} \times \mathrm{HO}(\mathrm{n}=46)$} & \multicolumn{2}{|c|}{$\mathrm{HO}(\mathrm{n}=33)$} & \multicolumn{2}{|c|}{$\mathrm{BS} \times \mathrm{HO}(\mathrm{n}=35)$} \\
\hline & LSM & $\mathrm{SE}$ & Difference & $\mathrm{SE}$ & LSM & $\mathrm{SE}$ & Difference & $\mathrm{SE}$ & LSM & SE & Difference & $\mathrm{SE}$ \\
\hline Milk (kg) & 8,887 & 225 & -170 & 205 & 10,483 & 240 & -190 & 227 & 10,729 & 252 & -347 & 241 \\
\hline Fat $(\mathrm{kg})$ & 356 & 9 & 5 & 8 & 424 & 9 & 10 & 9 & 438 & 10 & 5 & 9 \\
\hline Protein (kg) & 311 & 7 & 4 & 7 & 365 & 8 & 6 & 7 & 365 & 8 & 1 & 8 \\
\hline Fat plus protein $(\mathrm{kg})$ & 667 & 15 & 9 & 14 & 789 & 16 & 17 & 16 & 803 & 17 & 6 & 17 \\
\hline $\mathrm{SCS}$ & 2.35 & 0.13 & -0.18 & 0.11 & 2.86 & 0.14 & -0.25 & 0.13 & 3.10 & 0.15 & 0.26 & 0.15 \\
\hline
\end{tabular}

${ }^{1}$ Least squares means for Brown Swiss $\times$ Holstein cows are expressed as a difference from Holsteins. Differences were not significantly greater than zero $(P>0.05)$ in all cases.

Table 2. Number of observations, least squares means (LSM), and standard errors of means for total milking time and milking speed for the first 3 lactations for Holstein (HO) versus Brown Swiss $\times$ Holstein $(\mathrm{BS} \times \mathrm{HO})$ cows $^{1}$

\begin{tabular}{|c|c|c|c|c|c|c|c|c|c|c|c|c|}
\hline \multirow[b]{3}{*}{ Milking trait } & \multicolumn{4}{|c|}{ First lactation } & \multicolumn{4}{|c|}{ Second lactation } & \multicolumn{4}{|c|}{ Third lactation } \\
\hline & \multicolumn{2}{|c|}{$\mathrm{HO}(\mathrm{n}=50)$} & \multicolumn{2}{|c|}{$\mathrm{BS} \times \mathrm{HO}(\mathrm{n}=55)$} & \multicolumn{2}{|c|}{$\mathrm{HO}(\mathrm{n}=43)$} & \multicolumn{2}{|c|}{$\mathrm{BS} \times \operatorname{HO}(\mathrm{n}=46)$} & \multicolumn{2}{|c|}{$\mathrm{HO}(\mathrm{n}=33)$} & \multicolumn{2}{|c|}{$\mathrm{BS} \times \mathrm{HO}(\mathrm{n}=35)$} \\
\hline & LSM & $\mathrm{SE}$ & Difference & $\mathrm{SE}$ & LSM & $\mathrm{SE}$ & Difference & $\mathrm{SE}$ & LSM & $\mathrm{SE}$ & Difference & $\mathrm{SE}$ \\
\hline Milking time (s) & 294 & 8.30 & $35^{* *}$ & 7.94 & 294 & 8.36 & $51^{* *}$ & 7.99 & 285 & 8.33 & $30^{* *}$ & 7.98 \\
\hline Milking speed ( $\mathrm{kg} / \mathrm{min})$ & 2.07 & 0.06 & $-0.19^{*}$ & 0.06 & 2.31 & 0.06 & $-0.35^{* *}$ & 0.06 & 1.97 & 0.06 & $-0.19^{*}$ & 0.06 \\
\hline
\end{tabular}

${ }^{1}$ Least squares means for Brown Swiss $\times$ Holstein cows are expressed as a difference from Holsteins.

${ }^{*} P<0.05 ;{ }^{* *} P<0.01$. 
Table 3. Number of observations, least squares means (LSM), and standard errors of means for udder measurements for first and second lactation for Holstein $(\mathrm{HO})$ versus Brown Swiss $\times$ Holstein $(\mathrm{BS} \times \mathrm{HO})$ cows $^{1}$

\begin{tabular}{|c|c|c|c|c|c|c|c|c|}
\hline \multirow{2}{*}{ Udder trait } & \multicolumn{4}{|c|}{ First lactation } & \multicolumn{4}{|c|}{ Second lactation } \\
\hline & \multicolumn{2}{|c|}{$\mathrm{HO}(\mathrm{n}=50)$} & \multicolumn{2}{|c|}{$\mathrm{BS} \times \mathrm{HO}(\mathrm{n}=54)$} & \multicolumn{2}{|c|}{$\mathrm{HO}(\mathrm{n}=40)$} & \multicolumn{2}{|c|}{$\mathrm{BS} \times \mathrm{HO}(\mathrm{n}=45)$} \\
\hline Front teat length $(\mathrm{cm})$ & 4.8 & 0.11 & $0.3^{*}$ & 0.11 & 4.6 & 0.12 & $0.4^{*}$ & 0.16 \\
\hline Rear teat length $(\mathrm{cm})^{\prime}$ & 4.0 & 0.10 & $0.3^{* *}$ & 0.09 & 3.7 & 0.13 & $0.4^{*}$ & 0.13 \\
\hline Front teat diameter $(\mathrm{cm})$ & 2.1 & 0.04 & 0.1 & 0.04 & 2.3 & 0.06 & 0.1 & 0.06 \\
\hline Udder clearance rear $(\mathrm{cm})$ & 63.0 & 0.58 & $-3.0^{* *}$ & 0.50 & 58.0 & 0.67 & $-5.0^{* *}$ & 0.65 \\
\hline Front teat width $(\mathrm{cm})$ & 12.8 & 0.47 & 0.2 & 0.43 & 13.0 & 0.56 & 1.0 & 0.54 \\
\hline Rear teat width $(\mathrm{cm})$ & 4.7 & 0.36 & 0.3 & 0.33 & 4.7 & 0.45 & $1.6^{* *}$ & 0.44 \\
\hline Distance front to rear $(\mathrm{cm})$ & 10.7 & 0.28 & 0.4 & 0.26 & 13.0 & 0.33 & -0.5 & 0.33 \\
\hline Udder size $(\mathrm{cm})$ & 74.0 & 0.84 & 1.0 & 0.76 & 81.1 & 1.18 & $5.1^{* *}$ & 1.45 \\
\hline
\end{tabular}

${ }^{1}$ Least squares means for Brown Swiss $\times$ Holstein cows are expressed as a difference from Holsteins.

$* P<0.05 ; * *<0.01$.

found no differences between $\mathrm{BS} \times \mathrm{HO}$ cows and $\mathrm{HO}$ cows for SCS.

Least squares means for milking time and milking speed are outlined in Table 2. Total milking time was significantly $(P<0.01)$ longer for $\mathrm{BS} \times \mathrm{HO}$ cows compared with HO cows for first $(+35 \mathrm{~s})$, second $(+51 \mathrm{~s})$, and third $(+30 \mathrm{~s})$ lactations. Milking speed measured as yield per minute was significantly lower for $\mathrm{BS} \times$ HO compared with HO for first $(-0.19 \mathrm{~kg} / \mathrm{min})$, second $(-0.35 \mathrm{~kg} / \mathrm{min})$, and third $(-0.19 \mathrm{~kg} / \mathrm{min})$ lactations. At the time of the matings to produce offspring to be used in the trial, only some of the BS and $\mathrm{HO}$ sires had EBV for milking speed. A summary of the national EBV available in March 2011 revealed that BS sire EBV were rather variable relative to the German base for $\mathrm{BS}$ in this trait, whereas $\mathrm{HO}$ sires appeared to exhibit little variation relative to the Holstein base. For BS sires, sires B, C, and D had EBV substantially lower than the breed average, whereas sires A, G, H, and I had EBV above the breed average. For HO sires, only 1 sire showed an EBV of 1 SD below the reference base, whereas all others were around the breed average. In summary, BS sires were more variable in EBV for milking speed than HO sires, which might have an effect on the comparison of their offspring.

McDowell and McDaniel (1968) reported similar milking time and milking speed for $\mathrm{BS} \times \mathrm{HO}$ cows and $\mathrm{HO}$ cows when the model for analysis included milk yield. Without correction for milk yield, the same authors reported that $\mathrm{BS} \times \mathrm{HO}$ cows had a slower milking speed. Cows with a faster milking speed contribute to greater milking parlor efficiency. Differences in milking time and milking speed between genotypes are unfavorable for consistent milking of cows and emptying the parlor after milking. Although slow milking cows are undesir- able from a management point of view, cows that can be milked very fast have an increased risk of udder disorders. Boettcher et al. (1998) and Zwald et al. (2005) argued that an increase in milking speed could result in an increase in SCS. Similarly, Sewalem et al. (2010) concluded that selection against very slow milking cows would reduce the labor costs, whereas selection for very fast milking would increase SCC. However, differences between genotypes found in this study did not have a significant effect on either labor cost or udder health.

Least squares means for front teat length and rear teat length were significantly $(P<0.05)$ larger for BS $\times \mathrm{HO}$ cows compared with $\mathrm{HO}$ cows by $0.3 \mathrm{~cm}$ in first lactation and $0.4 \mathrm{~cm}$ in second lactation (Table 3). The $\mathrm{BS} \times \mathrm{HO}$ cows had significantly $(P<0.01)$ lower front udder clearance and rear udder clearance than $\mathrm{HO}$ cows during both lactations. In second lactation, rear teat width was significantly $(P<0.01)$ larger for $\mathrm{BS} \times$ $\mathrm{HO}$ cows than for $\mathrm{HO}$ cows, by $1.6 \mathrm{~cm}$. Udder size was significantly $(P<0.05)$ greater for BS $\times$ HO than for $\mathrm{HO}$ cows during second lactation, by $5.1 \mathrm{~cm}$. Weiss et al. (2004) reported no correlations between milkability traits and externally measurable teat characteristics for BS $\times$ German Braunvieh crossbred cows. The results from Weiss et al. (2004), however, may not be taken as a general rule when different genotypes are milked in the same parlor or substantial variation exists within genotypes. Variation in length and diameter of teats can cause problems if teats do not fit properly into the teat cups. This unfavorable interaction can expose more stress to the udder and to the cow. Furthermore, high variation in teat measurements will increase problems in robotic milking.

In conclusion, crossbreds from matings of BS AI bulls with $\mathrm{HO}$ cows are a competitive alternative with 
respect to production traits and SCS. However, milkability of $\mathrm{BS} \times \mathrm{HO}$ cows compared unfavorably with that of $\mathrm{HO}$ cows. Compared with $\mathrm{HO}$ cows, $\mathrm{BS} \times \mathrm{HO}$ cows had larger udders in second lactation. This could suggest a potential increase in udder health problems. However, the current study found no serious increase of $\mathrm{SCS}$ in $\mathrm{BS} \times \mathrm{HO}$ cows. A possible explanation for the reduced disease rate is that the teat canal of a slower milking cow closes faster after milking compared with that of a fast-milking cow.

\section{ACKNOWLEDGMENTS}

The authors thank Bernd Fischer and co-workers of the experimental station 'Iden' (Saxony-Anhalt, Germany) and Jessica Gühne (University of Halle, Germany) for their assistance in data collection and care of the animals.

\section{REFERENCES}

Blöttner, S., B. J. Heins, M. Wensch-Dorendorf, L. B. Hansen, and H. H. Swalve. 2011. Brown Swiss $\times$ Holstein crossbreds compared to pure Holsteins for calving traits, body weight, backfat thickness, fertility, and body measurements. J. Dairy Sci. 94:1058-1068.

Boettcher, P. J., J. C. M. Dekkers, and B. W. Kolstad. 1998. Development of an udder health index for sire selection based on somatic cell score, udder conformation, and milking speed. J. Dairy Sci. $81: 1157-1168$.

Cole, J. B., D. J. Null, and P. M. VanRaden. 2009. Best prediction of yields for long lactations. J. Dairy Sci. 92:1796-1810.

Dechow, C. D., G. W. Rogers, J. B. Cooper, M. I. Phelps, and A. L. Mosholder. 2007. Milk, fat, protein, somatic cell score, and days open among Holstein, Brown Swiss, and their crosses. J. Dairy Sci. 90:3542-3549.

González-Recio, O., R. Alenda, Y. M. Chang, K. A. Weigel, and D. Gianola. 2006. Selection for female fertility using censored fertility traits and investigation of the relationship with milk production. J. Dairy Sci. 89:4438-4444.

González-Recio, O., M. A. Pérez-Cabal, and R. Alenda. 2004. Economic value of female fertility and its relationship with profit in Spanish dairy cattle. J. Dairy Sci. 87:3053-3061.

Heins, B. J., L. B. Hansen, and A. J. Seykora. 2006a. Production of pure Holsteins versus crossbreds of Holstein with Normande, Montbeliarde, and Scandinavian Red. J. Dairy Sci. 89:2799-2804.
Heins, B. J., L. B. Hansen, and A. J. Seykora. 2006b. Calving difficulty and stillbirths of pure Holsteins versus crossbreds of Holstein with Normande, Montbeliarde, and Scandinavian Red. J. Dairy Sci. 89:2805-2810.

Heins, B. J., L. B. Hansen, and A. J. Seykora. 2006c. Fertility and survival of pure Holsteins versus crossbreds of Holstein with Normande, Montbeliarde, and Scandinavian Red. J. Dairy Sci. 89:4944-4951.

Heins, B. J., L. B. Hansen, A. J. Seykora, A. R. Hazel, D. G. Johnson, and J. G. Linn. 2011. Jersey $\times$ Holstein crossbreds compared with pure Holsteins for production, mastitis, and body measurements during the first 3 lactations. J. Dairy Sci. 94:501-506.

McDowell, R. E., and B. T. McDaniel. 1968. Interbreed matings in dairy cattle. I. Yield Traits, feed efficiency, type and rate of milking. J. Dairy Sci. 51:767-777.

Prendiville, R., K. M. Pierce, and F. Buckley. 2010. A comparison between Holstein-Friesian and Jersey dairy cows and their F1 cross with regard to milk yield, somatic cell score, mastitis, and milking characteristics under grazing conditions. J. Dairy Sci. 93:2741-2750.

Rincon, E. J., E. C. Schermerhorn, R. E. Mc Dowell, and B. T. McDaniel. 1982. Estimation of genetic effects on milk yield and constituent traits in crossbred dairy cattle. J. Dairy Sci. 65:848-856.

SAS Institute. 2004. SAS/STAT Software. Release 9.1.3. SAS Institute Inc., Cary, NC.

Sewalem, A., F. Miglior, and G. J. Kistemaker. 2010. Analysis of the relationship between workability traits and functional longevity in Canadian dairy breeds. J. Dairy Sci. 93:4359-4365.

Sørensen, M. K., E. Norberg, J. Pedersen, and L. G. Christensen. 2008 Invited review: Crossbreeding in dairy cattle: A Danish perspective. J. Dairy Sci. 91:4116-4128.

Swalve, H. H., N. Bergk, and Ph. Solms-Lich. 2008. Kreuzungszucht beim Milchrind - Ergebnisse aus einem Praxisbetrieb. Zuchtungskunde 80:429-442.

VanRaden, P. M., and A. H. Sanders. 2003. Economic merit of crossbred and purebred US dairy cattle. J. Dairy Sci. 86:1036-1044.

Walsh, S., F. Buckley, D. P. Berry, M. Rath, K. Pierce, N. Byrne, and P. Dillon. 2007. Effects of breed, feeding system, and parity on udder health and milking characteristics. J. Dairy Sci. 90:5767-5779.

Weiss, D., M. Weinfurtner, and R. M. Bruckmaier. 2004. Teat anatomy and its relationship with quarter and udder milk time characteristics in dairy cows. J. Dairy Sci. 87:3280-3289.

Wiggans, G. R., L. L. M. Thornton, R. R. Neitzel, and N. Gengler. 2007. Short communication: Genetic evaluation of milking speed for Brown Swiss dairy cattle in the United States. J. Dairy Sci. 90:1021-1023.

Zwald, N. R., K. A. Weigel, Y. M. Chang, R. D. Welper, and J. S. Clay. 2005. Genetic evaluation of dairy sires for milking duration using electronically recorded milking times of their daughters. J. Dairy Sci. 88:1192-1198. 